\title{
Anticancer effects induced by artichoke extract in oral squamous carcinoma cell lines
}

\author{
Nadia Fathy Hassabou* and Amina Fouad Farag
}

\begin{abstract}
Background: Oral squamous cell carcinoma is occupying the eighth position of all malignant neoplasia worldwide. Nowadays, natural compounds found in vegetables and fruits are important resources of many anticancer drugs especially those with high levels of phytochemicals representing an efficient strategy for cancer prevention and treatment. Artichoke (Cynara cardunculus L.) is a kind of antioxidant-rich vegetables demonstrated a potential anticancer activity on various types of cancer cells related to its content of phenolic compounds. Anticarcinogenic effects of polyphenolic extracts were reported to cause a reduction in cell viability, inhibition of cell growth, and initiation of apoptotic mechanisms. The present study aimed to investigate the cell cycle arrest, cytotoxic, and apoptotic effects of artichoke extract against the invasive oral squamous cell carcinoma.

Results: A pure extract from the edible part and leaves of fresh artichoke was added to oral squamous carcinoma cell lines and to control group to evaluate the expression of caspase-9, Bcl-2, and Bax genes. Artichoke extract demonstrated the highest cytotoxic effect against cancer cell lines which increased in a time-dependent manner. No apparent effects were observed in the normal control group. Expression of Bax and caspase-9 genes revealed a highly significant increase in cancer cell lines $(p=0.0001)$ when compared to the control group. In addition to a highly significant decrease $(p=0.005)$ in Bcl-2 of cancer cells. It was demonstrated that artichoke extract induced cell growth arrest at G2/M phase which revealed a significant increase $(p<0.05)$ in comparison to the untreated control group.
\end{abstract}

Conclusion: Artichoke exerts potent cell cycle arrest, cytotoxic, and apoptotic effects on oral squamous carcinoma cell lines.

Keywords: Artichoke, SCC-25 cell lines, Cytotoxicity, Apoptosis

\section{Background}

Oral cancer is considered one of the main causes of death worldwide with oral squamous cell carcinoma (OSCC) occupying the eighth position in the cancer incidence ranking, and its associated deaths reached 1310 or $0.25 \%$ of total deaths in Egypt in 2017 according to the latest WHO data. This aggressive epithelial malignancy is considered a threat to public health due to the capabilities of its cells to locally invade the surrounding tissues in addition to

* Correspondence: dr_nadia_hassabou@hotmail.com

Oral and maxillofacial pathology, Faculty of Dentistry, October 6 University, Giza 12585, Egypt

\section{Springer Open}

(c) The Author(s). 2020 Open Access This article is licensed under a Creative Commons Attribution 4.0 International License, which permits use, sharing, adaptation, distribution and reproduction in any medium or format, as long as you give appropriate credit to the original author(s) and the source, provide a link to the Creative Commons licence, and indicate if changes were made. The images or other third party material in this article are included in the article's Creative Commons licence, unless indicated otherwise in a credit line to the material. If material is not included in the article's Creative Commons licence and your intended use is not permitted by statutory regulation or exceeds the permitted use, you will need to obtain permission directly from the copyright holder. To view a copy of this licence, visit http://creativecommons.org/licenses/by/4.0/. 
Many epidemiological studies over the past years suggest that diets particularly rich in vegetables and fruits have anticarcinogenic effects and apoptosis triggering properties [6-8]. These have been attributed to the presence of high levels of phytochemicals in vegetables and fruits which can be an efficient strategy for cancer prevention and treatment [9].

Nevertheless, the mechanisms of modulation and induction of apoptosis by these natural compounds are still unclear. Natural phytochemicals containing phenolic compounds have antitumor and anti-metastatic properties [10] that can be attributed at least in part to polyphenols both in vitro and in animal models [11].

The current growing interest in dietary plants has led to renewed interest in artichoke because of its high polyphenolic content. Artichoke polyphenols represent up to $2 \%$ of the fresh weight, mainly hydroxycinnamic derivates (0.5$1.5 \%)$, and in the edible part, they are mainly represented by mono- and di-caffeoylquinic acids. The bioavailability of metabolites of hydroxycinnamic acids after ingestion of cooked edible artichokes has also been demonstrated [12].

The flowers of artichoke (Cynara cardunculus L.) have a well-recognized history of consumption as a food, especially as part of the Mediterranean diet. This plant is usually cultivated for its leaves which are blanched and eaten as a vegetable (cardoon, artichoke). The edible, fleshy leaves (bracts) of the artichoke are cooked and eaten worldwide. They are also recognized for their potential therapeutic effects including inhibiting the biosynthesis of cholesterol, low-density lipoprotein oxidizing, mobilizing energy reserves, and inducing choleresis, along with antibacterial, antioxidant, and hepatoprotective effects [13]. These beneficial effects appear to be related to its content of phenolic compounds.

Flavones with their glycosides, caffeoylquinic acids, and triterpenoid saponins are active constituents found in the extract of Cynara cardunculus L. with several antioxidant and antigenotoxic activities [14].

Artichoke as an ancient plant grown mainly in Egypt, Italy, and Spain has been used for so long as a vegetable in traditional medicine against liver complaints. It showed marked choleretic, hepatoprotective, hypocholesterolemic, and antioxidative potentials. Furthermore, they exhibited cancer chemopreventive properties by triggering apoptosis on human hepatoma cells [15]. Mileo et al. [16] studied the anticarcinogenic effects of polyphenolic extracts from the edible part of artichokes. They observed a reduction in cell viability, inhibition of cell growth, and initiation of apoptotic mechanisms against the invasive breast cancer cell line with no effect on normal breast epithelial cell line. They reported chlorogenic acid (ChA) to be the most representative component of the polyphenolic fraction of artichoke as it triggered the apoptosis via a mitochondrial and a deathreceptor pathway, as shown by the activation of caspase-9 (CASP-9) and CASP-8. Furthermore, an increase of the Bax-Bcl-2 ratio, upregulation of cyclin-dependent kinase inhibitor p21, WAF1, and a loss of mitochondrial transmembrane potential were documented.

The potential anticarcinogenic effects of artichoke extract on model cell cultures have not been thoroughly investigated and furthermore have never been studied on the oral cancer. Therefore, this study was conducted to examine the induction of cell cycle arrest, antiproliferative, and apoptotic effects of artichoke extract on the squamous cell carcinoma (SCC) cell lines.

\section{Methods}

\section{Preparation of plant extract}

The samples of the fresh artichoke (Cynara scolymus L.) were collected from Nahia region, Giza, Egypt, in February 2019. The cultivar is known as Balady. The formal identification of the samples was undertaken by authors, and a voucher specimen (numbered 5.2.2019) has been located at the herbarium associated with our institution. The edible part (head) and leaves of fresh artichoke were used for extract preparation. They were dried and ground into fine powder using a blender. To prepare the aqueous artichoke extract, each $10 \mathrm{~g}$ of powder was soaked within $200 \mathrm{ml}$ boiling distilled water for $15 \mathrm{~min}$ and allowed to cool down at room temperature. To obtain ethanolic artichoke extract, $50 \mathrm{~g}$ of the ground herbs was soaked in $500 \mathrm{ml} 50 \%$ ethanol solution for $24 \mathrm{~h}$ at room temperature, then the mixtures were filtered and passed sequentially through a $0.22-\mu \mathrm{m}$ filter. The extract was concentrated by rotary evaporator and stored at $-20{ }^{\circ} \mathrm{C}$ at the National Research Institute, Egypt. The concentrated extracts were dissolved in dimethyl sulphoxide (DMSO) (Sigma, USA) to get a stock solution of $10 \mathrm{mg} / \mathrm{mL}$ [17].

\section{Cell culture protocol}

Human lung normal cell lines (WI-38) and human tongue SCC cell lines (SCC-25) were obtained from American Type Culture Collection, and cells were cultured using DMEM (Invitrogen/Life Technologies) by the Holding Company for Biological Products \& Vaccines, Egypt (VACSERA). Cells were maintained in RPMI 1640 culture medium (Gibco, USA) and supplemented with $10 \%$ FBS (Hyclone), $10 \mathrm{ug} / \mathrm{ml}$ of insulin (Sigma), and $1 \%$ antibiotic-antimycotic solution (penicillin-streptomycin) (Invitrogen, USA). All of the other chemicals and reagents were from Sigma and Invitrogen. 
The culture medium was removed to a centrifuge tube. The cell layer briefly rinsed with $0.25 \%(\mathrm{w} / \mathrm{v})$ Trypsin $0.53 \mathrm{mM}$ EDTA solution to remove all traces of serum which contains Trypsin inhibitor. About 2.0 to $3.0 \mathrm{ml}$ of Trypsin EDTA solution was added to the flask and the cells were observed under an inverted microscope until the cell layer is dispersed (usually within 5 to $15 \mathrm{~min}$ ). To avoid clumping, do not agitate the cells by hitting or shaking the flask while waiting for the cells to detach. Cells that are difficult to detach may be placed at $37{ }^{\circ} \mathrm{C}$ to facilitate dispersal.

Complete growth medium (6.0 to $8.0 \mathrm{ml})$ was added, and then the cells were aspirated by gently pipetting. The cell suspension was transferred to the centrifuge tube with the medium and cells from the previous step and centrifuge at approximately $125 \times g$ for 5 to $10 \mathrm{~min}$ to discard the supernatant. Fresh growth medium was used to re-suspend the cell pellet, and appropriate aliquots of the cell suspension were added to new culture vessels. All cell culture experiments were carried out at $37{ }^{\circ} \mathrm{C}$ in a $100 \%$ humidified incubator containing $5 \% \mathrm{CO}_{2}$.

Artichoke extract was added on the first day of treatment to SCC-25 cell lines and to healthy cell lines that have been used as a control. Incubation was carried out for 24 and $48 \mathrm{~h}$ at $37{ }^{\circ} \mathrm{C}$, after the plates were examined under the inverted microscope and proceeded for the MTT assay. PCR was done after incubation. DNA and RNA were extracted from cells using quantitative realtime PCR.

\section{MTT-cytotoxicity assay protocol}

Plate cells (cells density $1.2-1.8 \times 10,000$ cells/well) in a volume of $100 \mu$ l complete growth medium $+100 \mathrm{ul}$ of the tested compound per well for $24 \mathrm{~h}$ before the microculture tetrazolium assay (MTT) assay.

MTT method of monitoring in vitro cytotoxicity is well suited for use with multi-well plates. Cultures were removed from the incubator into a laminar flow hood or other sterile work areas. Each vial of MTT [M-5655] was reconstituted to be used with $3 \mathrm{ml}$ of medium or balanced salt solution without phenol red and serum.

Reconstituted MTT was added in an amount equal to $10 \%$ of the culture medium volume. Cultures were returned to the incubator for $2-4 \mathrm{~h}$ depending on cell type and maximum cell density. An incubation period of $2 \mathrm{~h}$ is generally adequate but may be lengthened for low cell densities or cells with lower metabolic activity.

After the incubation period, cultures were removed from the incubator and the resulting formazan crystals were dissolved by adding an amount of MTT solubilization solution [M-8910] equal to the original culture medium volume. Gentle mixing in a gyratory shaker was performed to enhance dissolution and spectrophotometrically measure absorbance at a wavelength of $570 \mathrm{~nm}$. The background absorbance of multi-well plates was measured at $690 \mathrm{~nm}$ and subtracted from the 450-nm measurement.

\section{Annexin-V/PI dual staining assay}

Fluorescein isothiocyanate (FITC) was used to perform a quantitative assessment of apoptosis by using propidium iodide (PI) flow cytometry (ab139418) detection kit/ BD. Cells were cultured overnight $(1.5 \times 105$ cells $)$ in $25 \mathrm{~cm}^{2}$ cell culture flasks before addition of artichoke extract. Cells were then treated with IC50 value of the extract which is $(102.74 \mathrm{ug} / \mathrm{ml})$ for 24 and $(184.81 \mathrm{ug} / \mathrm{ml})$ for $48 \mathrm{~h}$.

The positive control was prepared by culturing the control SCC-25 cell lines in medium containing $200 \mathrm{ml} \mathrm{H}_{2} \mathrm{O}_{2}$ for $30 \mathrm{~min}$. Cells were collected, washed twice with cold PBS, and re-suspended in binding buffer $(1 \times 105$ cells $/ \mathrm{ml})$. Cells were transferred to a tube with addition of $5 \mu \mathrm{l}$ of FITC-conjugated annexin-V (annexin-V FITC) and $5 \mu \mathrm{l}$ of PI (PI $50 \mathrm{mg} / \mathrm{ml}$ ) followed by incubation for $15 \mathrm{~min}$ at room temperature.

The stained cells were diluted by the binding buffer and analyzed by the flow cytometer (BD FACSCalibur). Apoptotic cells are reflected by quantification of annexin-V FITC binding to externalized PS. In flow cytometry analysis, annexin-V/PI staining is based on the ability of the protein annexin- $\mathrm{V}$ to bind to PS, which is externalized in the outer cell membrane upon induction of apoptosis. Four different populations of cells were distinguished: cells that were unlabeled (viable cells), those that have bound to annexin-V FITC only (early apoptotic), those that have been stained with PI (necrotic), and those that have both bound to annexin-V FITC and been labeled with PI (late apoptotic).

The fluorescence distribution was displayed as a color dot plot analysis, and the fluorescent cell percentage in each quadrant was determined.

\section{Light microscopic studies}

Inverted light microscope was used at magnification $(\times 200)$ to investigate the morphological alterations of apoptosis induced by artichoke extract in both healthy and SCC-25 cell lines at $24 \mathrm{~h}$ and $48 \mathrm{~h}$.

\section{Cell cycle analysis}

Flow cytometry analysis was used to evaluate the percentage of DNA content in each phase of the cell cycle. SCC-25 cells were cultured in multi-well plates overnight and then treated with artichoke extract. The Cycletest $^{\mathrm{TM}}$ Plus DNA Reagent Kit (BioVision, USA) was used to determine the cell cycle phase distributions. 
Table 1 Primers sequence for all studied genes in the work

\begin{tabular}{lll}
\hline Gene & Primer type & Primer sequences (5' to 3') \\
\hline CASP-9 & RT-PCR & CASP9-F 5'-CCA GAG ATT GCG AAA CCA GAG G-3' \\
& Forward/reverse & CASP9-R 5'-GAG CAC CGA CAT CAC CAA ATT C-3' \\
BAX & RT-PCR & Bax F 5'-GCG AGT GTC TCA AGC GCA TC-3' \\
& Forward/reverse & Bax R 5'-CCA GTT GAA GTT GCC GTC AGA A-3' \\
BCL-2 & RT-PCR & BCl-2 F 5'-GATGTGATGCCTCTGCGAAG-3' \\
& Forward/reverse & BCl-2 R 5'-CATGCTGATGTCTCTGGAATCT-3' \\
$\beta$-actin & RT-PCR & B-actin F 5'-TGC CGA CAG GAT GCA GAA G-3' \\
& Forward/reverse & B-actin R 5'-GCC GAT CCA CAC GGA GTA CT-3' \\
\hline
\end{tabular}

Nuclei were isolated, stained with PI, and analyzed on FACSCalibur flow cytometer according to the instructions of the manufacturer. The percentages of DNA in each cell cycle phase were analyzed using ModFit software (ModFit, Topsham, ME, UK).

\section{Quantitative real-time PCR RNA extraction}

Total RNA was isolated from cell culture according to instructions of manufacture using Qiagen extraction kit (Qiagen, USA). RNA extraction was performed on in vitro cells. Centrifugation of SCC- 25 cells was performed for $3 \mathrm{~min}$ at full speed. The supernatant was removed and transferred to a new micro-centrifuge tube. One volume of $70 \%$ ethanol $(300 \mu \mathrm{l})$ was added to the cleared lysate.

About $700 \mu \mathrm{l}$ of the sample was transferred to RNeasy spin column that was placed in a collection tube and centrifuged for $15 \mathrm{~s}$ at $\geq 8000 \mathrm{rpm}$. RNasefree water was added directly to the spin column membrane and centrifuged for $1 \mathrm{~min}$ at $\geq 8000 \mathrm{rpm}$ to isolate the RNA.

The isolated RNA was transferred to a new Eppendorf tube and stored at $-80{ }^{\circ} \mathrm{C}$. Quantification of RNA was performed in duplicate using spectrophometry at 260 $\mathrm{nm}$ (dual wavelength Beckman, Spectrophotometer, USA).

\section{Sequence of real-time PCR primers}

Primer sequences $\left(5^{\prime}\right.$ to $\left.3^{\prime}\right)$ for all studied genes are demonstrated (Table 1).

\section{cDNA synthesis}

The total RNA $(0.5-2 \mu \mathrm{g})$ was used for cDNA conversion using high-capacity cDNA reverse transcription kit (Fermentas, USA).
Moloney murine leukemia virus (MMLV) reverse transcriptase was used for the synthesis of cDNA from RNA. It is an RNA-dependent DNA polymerase that uses single-stranded RNA as a template in the presence of a primer to synthesize a complementary DNA strand.

Human placental ribonuclease inhibitor (HPRI) was used for inhibition of RNase activity. The cDNA master mix was prepared according to the kit instructions and was added for each sample. The mixture was incubated in the programmed thermal cycler for $1 \mathrm{~h}$ at $37{ }^{\circ} \mathrm{C}$ followed by inactivation of enzymes at $95{ }^{\circ} \mathrm{C}$ for $10 \mathrm{~min}$ and finally cooled at $4{ }^{\circ} \mathrm{C}$. Then, RNA was changed into cDNA and the converted cDNA was stored at $-20^{\circ} \mathrm{C}$.

\section{Real-time $q P C R$ amplification}

Real-time qPCR amplification and analysis were performed using an Applied Biosystem with software version 3.1 (StepOne ${ }^{\mathrm{m} x}$, USA). The $\mathrm{qPCR}$ assay with the primer sets was optimized at the annealing temperature. All cDNA was duplicated and including previously prepared samples. The thermal cycling conditions for RTPCR comprised an initial denaturation step at $95{ }^{\circ} \mathrm{C}$ for $30 \mathrm{~s}$, then 45 cycles at an appropriate annealing temperature depending on the primer set for $1 \mathrm{~min}$.

\section{Calculation of relative quantification (RQ)}

Threshold cycle $(\mathrm{Ct})$ number is the value where the PCR curve crosses the threshold in the linear part of the curve. Endogenous controls are the gene that does not vary between all of the samples tested. The calibrator is the sample that all others are compared to. It is the "untreated" or "time zero." The RQ is a technique used to analyze the fold changes in gene expression in a given sample compared to a calibrator. These values were necessary for the calculations described below [18].

$\Delta \mathrm{Ct}=\mathrm{Ct}$ gene test $-\mathrm{Ct}$ endogenous control

Table 2 Mean values and variability of measures (SD) of cytotoxicity of artichoke extract on SCC-25 cell lines at 24 and 48 h using paired samples Student's $t$ test

\begin{tabular}{lll}
\hline Sample code & Cytotoxicity IC50 ug/ml & Cytotoxicity IC50 ug/ml \\
& at $24 \mathrm{~h}$ & $\begin{array}{l}\text { at } 48 \mathrm{~h} \\
\text { SCC-25 }\end{array}$ \\
\hline Artichoke extract/SCC-25 & SCC-25 & $184.81 \pm 9.52$ \\
\hline
\end{tabular}


Table 3 Mean values and measures of variability (SE) of studied genes expression in control and artichoke SCC-25 cell lines in relation to the time of influence using paired Student's t test

\begin{tabular}{|c|c|c|c|c|c|c|}
\hline \multirow[t]{3}{*}{ Sample code } & \multicolumn{6}{|l|}{ Fold changes } \\
\hline & \multicolumn{2}{|l|}{$\mathrm{BCL}-2$} & \multicolumn{2}{|l|}{ CASP-9 } & \multicolumn{2}{|l|}{ BAX } \\
\hline & $24 \mathrm{~h}$ & $48 \mathrm{~h}$ & $24 \mathrm{~h}$ & $48 \mathrm{~h}$ & $24 \mathrm{~h}$ & $48 \mathrm{~h}$ \\
\hline Control/SCC-25 & $1.02 \pm 0.02$ & $1 \pm 0.009$ & $1.06 \pm 0.03$ & $1.01 \pm 0.02$ & $1 \pm 0.07$ & $1.020 \pm 0.013$ \\
\hline Artichoke/SCC-25 & $0.6734 \pm 0.028$ & $0.3800 \pm 0.008$ & $3.8570 \pm 0.05$ & $4.6367 \pm 0.07$ & $2.9034 \pm 0.06$ & $3.5766 \pm 0.04$ \\
\hline
\end{tabular}

$\Delta \Delta \mathrm{Ct}=\Delta \mathrm{Ct}$ sample $-\Delta \mathrm{Ct}$ calibrator

$\mathrm{RQ}=$ Relative quantification $=2^{-\Delta \Delta C t}$

\section{Statistical analysis}

Scores of overall expressed genes were reported as mean values and standard deviation using SPSS (Statistical Package for Social Sciences) 16.0 software. Mean values between the studied groups were compared using paired samples Student's $t$ test. $P$ value was considered highly significant when $\leq 0.01$ and significant when $\leq 0.05$.

\section{Results}

\section{MTT cytotoxicity assay}

In the present work, the cytotoxic effect of artichoke extract was evaluated by MTT assay. It was observed that there was no apparent cytotoxicity of the artichoke extract on the healthy cell lines that have been used as a control group. The current results showed cytotoxic and antiproliferative effects of artichoke extract on SCC-25 cell lines which is in time-dependent manner that was represented as mean \pm SD and showed a significant increase $(p \leq 0.05)$ from 24 to $48 \mathrm{~h}$ of influence (Table 2).

\section{Fold changes in gene expression}

Cytotoxic and anti-proliferative effects of the artichoke were represented as mean $\pm \mathrm{SE}$ values of gene expression (Table 3). A highly significant decrease was observed in $\mathrm{Bcl}-2$ gene expression $(p=0.005)$. Expression of CASP-9 and BAX genes revealed a highly significant increase $(p=0.0001)$ when SCC-25 cell lines treated with the artichoke extract group compared to the control one (Fig. 1).

\section{Artichoke extract induced apoptosis in SCC-25}

In the current study, cell death induced by artichoke extract was investigated for apoptotic activity by monitoring phosphatidylserine (PS) translocation using the annexin-V FITC/PI assay. Four populations of cells were distinguished from our current results by Annexin-V/PI staining, viable cells $\left(\mathrm{AnnV}^{-} / \mathrm{PI}^{-}\right)$, early apoptotic cells $\left(\mathrm{AnnV}^{+} / \mathrm{PI}^{-}\right)$, late apoptotic cells $\left(\mathrm{AnnV}^{+} / \mathrm{PI}^{+}\right)$, and necrotic cells $\left(\mathrm{AnnV}^{-} / \mathrm{PI}^{+}\right)$(Fig. 2a, b).

The flow cytometry analysis of SCC-25 cell lines showed that through the treatment with artichoke extract, the cell population tended to shift from viable to apoptotic which is time dependent from 24 to $48 \mathrm{~h}$. The early apoptotic rates were $(0.75$ and $0.89 \%)$, respectively demonstrating

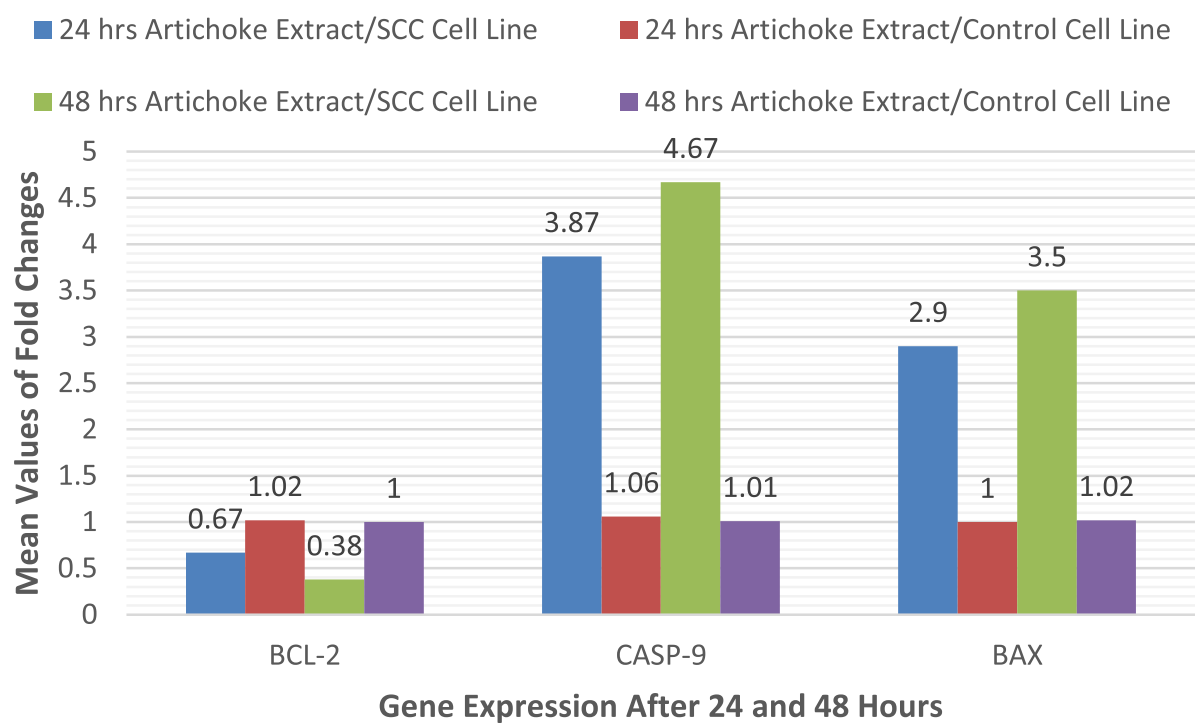

Fig. 1 Mean values of fold changes in gene expression occurred in studied control and SCC-25 cell lines after 24 and $48 \mathrm{~h}$ 


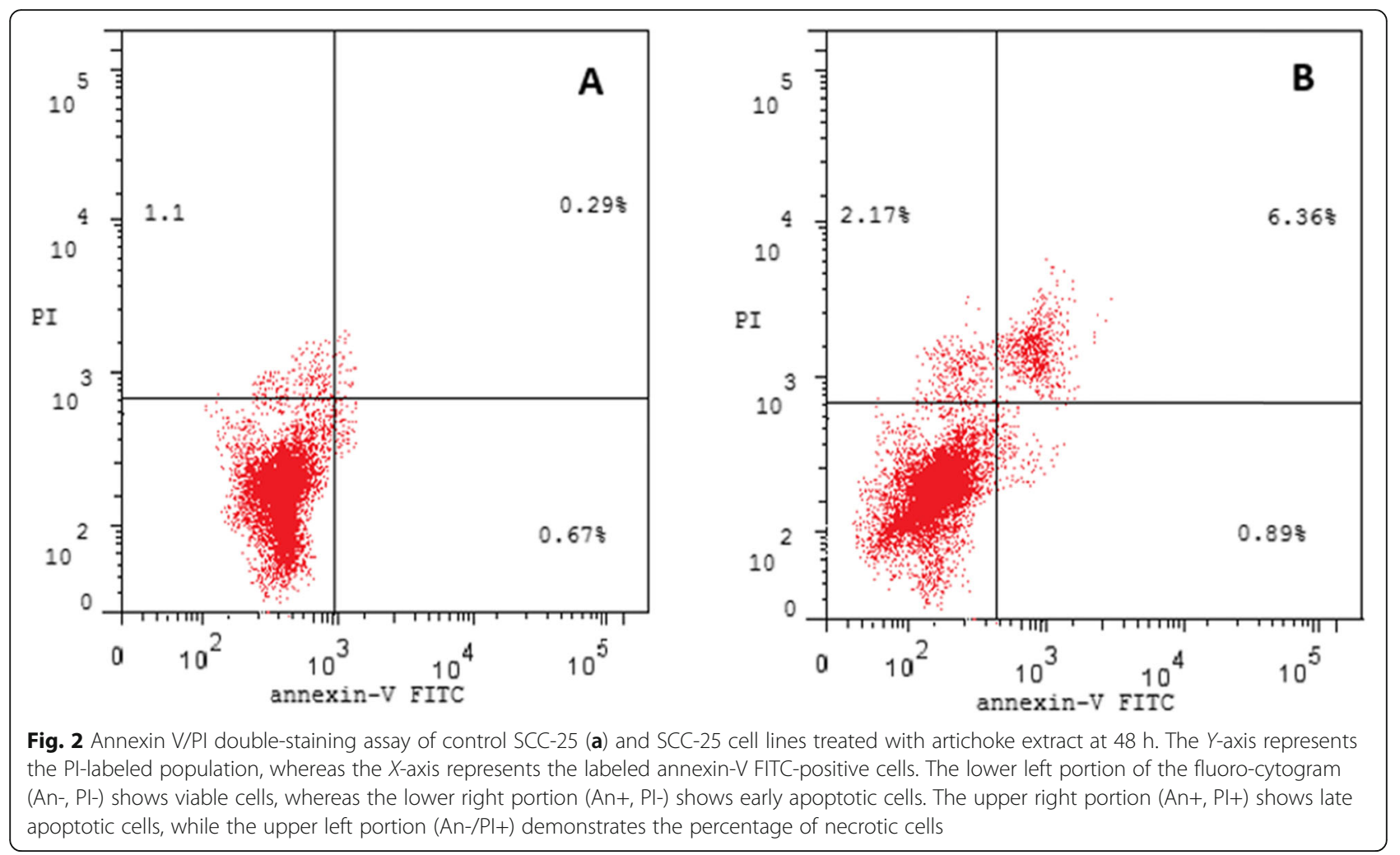

non-significant differences when compared with the rate of positive control (0.67\%) (Table 4, Fig. 3).

Furthermore, highly significant changes $\left(p \leq 0.001^{* *}\right)$ in the percentage of the late-stage apoptotic cells for artichoke extract-treated SCC-25 group were observed at 24 and $48 \mathrm{~h}$ of incubation (4.97 and $6.32 \%$ ), respectively as compared to $0.29 \%$ of the positive control group (Table 4, Fig. 3).

Our study revealed that rates of necrotic cells have no significant differences when comparing positive control group to artichoke/SCC-25 group that were $1.1 \%$ and $2.17 \%$ respectively at $48 \mathrm{~h}$. These results demonstrated the ability of artichoke extract to exert an apoptotic effect on SCC-25 cell lines particularly in the late stage of apoptosis which is an irreversible process.

\section{Light microscopic studies}

Morphological investigation of apoptosis by inverted light microscope in our study revealed that artichoke extract induced cell death in SCC-25 cell lines by apoptosis, and no morphological changes were observed in normal healthy cell lines. Phenotypically, apoptosis is characterized by cell shrinkage, chromatin condensation, DNA fragmentation, and collapse of the cell into minute fragments (apoptotic bodies).

Our microscopic results showed an increase in the number of apoptotic cells corresponding to the time of incubation with artichoke extract (Fig. 4). Round or oval masses of cytoplasm appeared which referred to apoptotic bodies.

\section{Cell cycle analysis}

After SCC-25 cells were incubated with artichoke extract, they were isolated to examine the effects on cell cycle by flow cytometry. The results of the current work demonstrated that artichoke extract induced cell growth arrest at G2/M phase (Fig. 5a, b). After $48 \mathrm{~h}$ of treatment with the artichoke extract, a significant increase $(p<$

Table 4 Percentages of distinguished cell populations by annexin-V FITC flow cytometry analysis in both control- and artichoketreated SCC-25 cell lines using paired Student's $t$ test and the results were represented as mean \pm SE

\begin{tabular}{|c|c|c|c|c|c|c|c|c|}
\hline \multirow[t]{3}{*}{ Sample data } & \multicolumn{4}{|l|}{ Apoptosis } & \multicolumn{2}{|l|}{ Necrosis } & \multicolumn{2}{|l|}{ Total } \\
\hline & \multicolumn{2}{|l|}{ Early } & \multicolumn{2}{|l|}{ Late } & & & & \\
\hline & $24 \mathrm{~h}$ & $48 \mathrm{~h}$ & $24 \mathrm{~h}$ & $48 \mathrm{~h}$ & $24 \mathrm{~h}$ & $48 \mathrm{~h}$ & $24 \mathrm{~h}$ & $48 \mathrm{~h}$ \\
\hline Artichoke/SCC25 & $0.75 \pm 0.05$ & $0.89 \pm 0.04$ & $4.97 \pm 0.19$ & $6.36 \pm 0.21$ & $1.93 \pm 0.03$ & $2.17 \pm 0.04$ & $7.65 \pm 0.21$ & $9.42 \pm 0.28$ \\
\hline Control/SCC25 & $0.60 \pm 0.02$ & $0.67 \pm 0.02$ & $0.21 \pm 0.03$ & $0.29 \pm 0.03$ & $1 \pm 0.02$ & $1.1 \pm 0.03$ & $1.81 \pm 0.04$ & $2.06 \pm 0.07$ \\
\hline
\end{tabular}




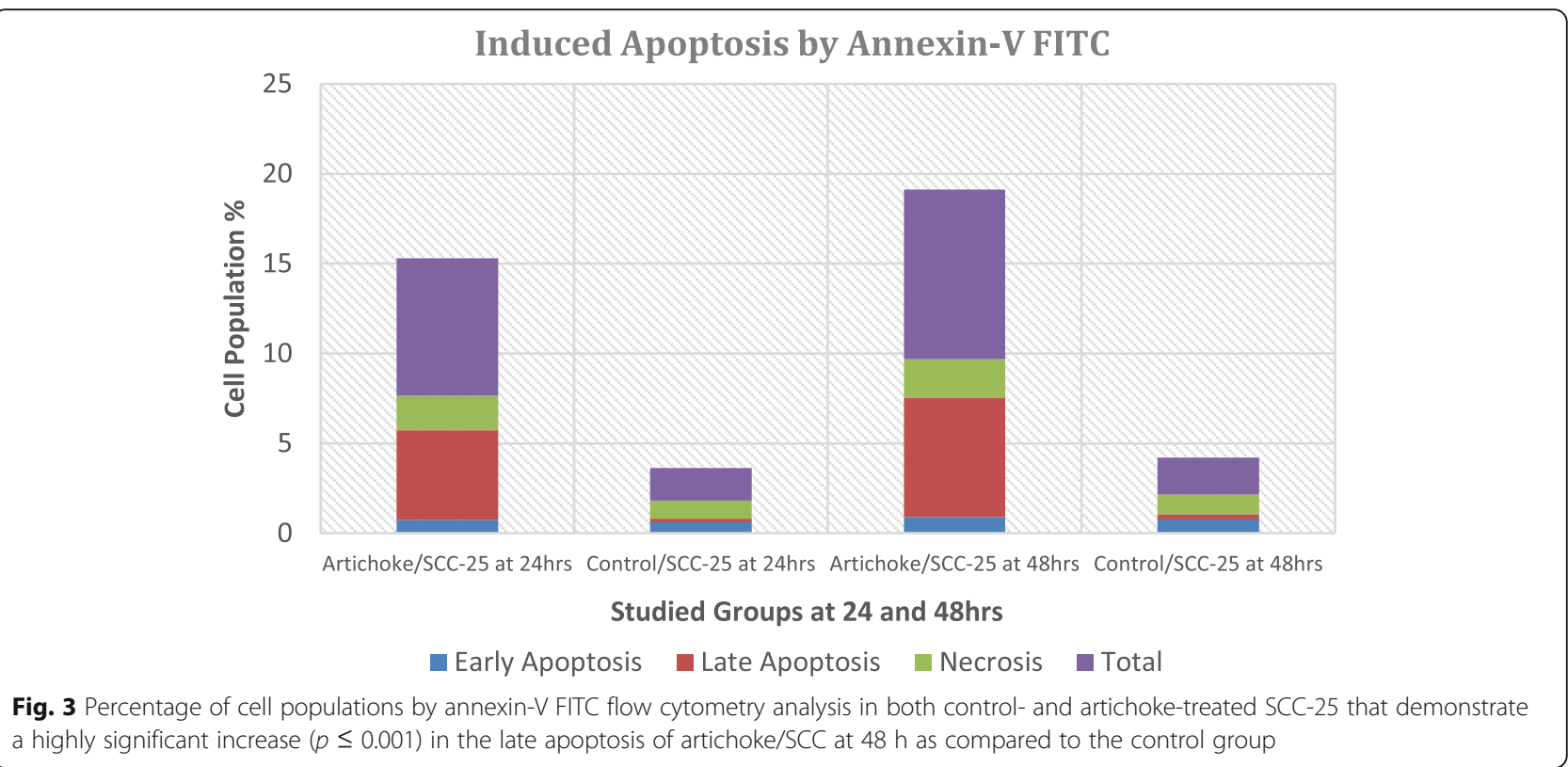

0.05) in the number of cells arrested at the G2/M growth phase was observed as compared the control group of SCC-25, (Table 5, Fig. 6).

\section{Discussion}

Currently, cancer is one of the deadliest diseased worldwide. World Health Organization (WHO) in 2012 reported that 8.2 million people died with cancer. About $30 \%$ of the most common cancers such as breast, colorectal, cervical, and oral cancer can be prevented or curable if treated promptly [19].

Cancer is a disease characterized by unlimited proliferation of cells which may spread to different parts of the body. Angiogenesis is an important factor for proliferating and spreading of cancer cells. The whole process of tumorigenesis and rate of tumor progression depends on the balance between proliferation and apoptosis of the cancer cells [20].
Oxidative stress is one of the most important factors that cause cancer and a well-studied event that gives rise to the conditions leading to tumor onset and progression [4]. It has been demonstrated that continuous inflammation may lead to a preneoplastic situation. Chronically inflamed cells secrete a higher amount of reactive oxygen/ nitrogen species which recruit more activated immune cells to overcome endogenous antioxidant response leading to the amplification of dysregulated processes and an irreversible oxidative damage to nucleic acids, proteins, and lipids which may cause genetic and epigenetic modifications. This leads to the dysregulation of oncogenes and tumor suppressor genes that drive the initiation of carcinogenesis [21].

Nowadays, it is well known that chemoprevention is a promising strategy which depends on natural dietary products and synthetic substances that not only offer protection against oxidative reaction but also provide

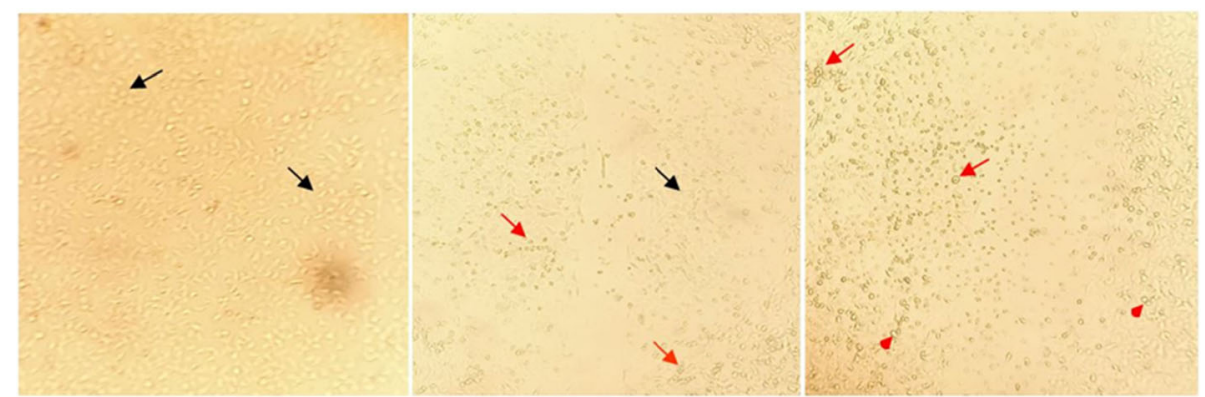

Fig. 4 Morphological changes of SCC-25 cells treated with artichoke extract for $\mathbf{b} 24 \mathrm{~h}$ and $\mathbf{c} 48 \mathrm{~h}$ viewed under an inverted light microscope Control SCC-25 (a) was also included ( $\times 200$ magnification). Black arrows showed normal viable cells while red arrows showed cell shrinkage and nuclear condensation due to apoptosis. Red arrowheads showed the presence of apoptotic bodies 


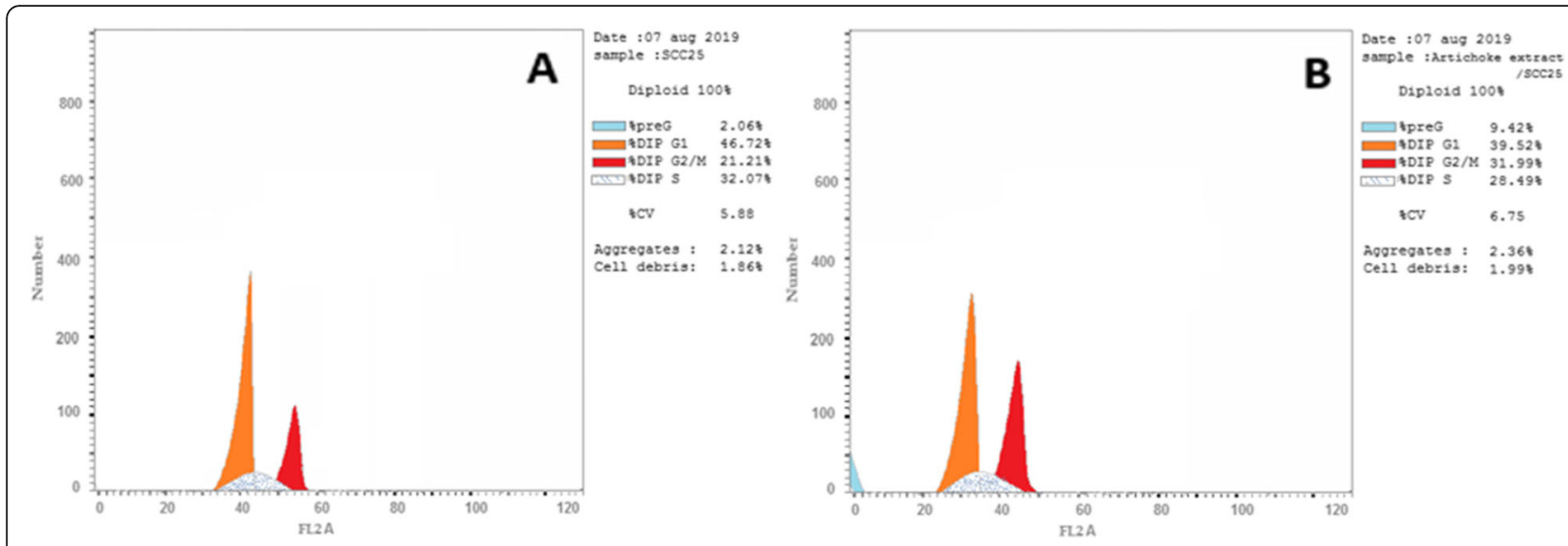

Fig. 5 Artichoke extract induces cell cycle arrest in SCC-25 cell lines. Flow cytometric analysis was performed for cell cycle distribution. The DNA content was evaluated with PI staining, fluorescence measured, and analyzed. Representative flow cytometry graph for untreated control SCC-25 group (a) and artichoke-treated SCC-25 group (b)

important preventive mechanisms including suppression of cell proliferation, apoptosis, and modulation of epigenetic processes [22].

There are lines of evidence and many epidemiological studies indicating that medicinal plants and diets particularly rich in fruits and vegetables constitute a common alternative for cancer prevention and treatment in many countries around the world [23].

Many researchers worldwide demonstrated that anticancer beneficial effect of diets is attributable to polyphenol, brassinosteroid, and taxol compounds which have antiproliferative activities both in animal models and in humans [24]. Therefore, the current work was conducted to examine anticancer properties of artichoke extract on oral squamous carcinoma cell lines.

The artichoke is an ancient herbaceous plant, originating from the Mediterranean area. Today, it is widely cultivated all over the world [25]. It is a promising medicinal plant as its extracts exert antiproliferative, anti-invasive, and antimetastatic effects; induce apoptosis through modulation of antiapototic proteins such as Bcl2; and increase p53, p21, and p27. Several antioxidant bioactive compounds had been identified in globe artichoke, and their antioxidant activities were confirmed in multiple pre-clinical studies [23].

The results of the current work confirmed that treatment with artichoke extract inhibits proliferation of cancer cell. The present results showed cytotoxic and antiproliferative effects of applied artichoke extract on cancer cells achieved from SCC-25 cell lines that represent significant increase which is time dependent. Also, no effects on the normal cells have been revealed. The obtained findings were in accordance with earlier studies that were conducted to evaluate antitumor and apoptotic properties of artichoke extract in different cancer cell lines $[17,22]$.

Apoptosis is a genetically programmed mechanism which promotes the beginning of tumorgenesis when subjected to inhibition. It is associated with the expression of two synergistically acting genes that encode antiand pro-apoptotic proteins. It is well known that Bax gene promotes apoptosis while $\mathrm{Bcl}-2$ gene enhances cell survival [26].

One of the most important events in carcinogenesis is the mutation of p53 tumor suppressor gene. Cells with a mutated p53 gene tend to escape from apoptosis. Apart from the cell-cycle regulation, increasing evidence suggests that caspase family proteases that play an important role in the mechanism of apoptosis. In apoptosis, caspase are indispensable enzymes that control the pathway [27].

Apoptotic frequency and antiproliferative potential in our study represented by an increase in the expression of CASP-9 and Bax genes which were inversely

Table 5 Percentage of DNA content during phases of the cell cycle in control and artichoke extract/SCC25 using paired Student's t test and variability of measures (SD)

\begin{tabular}{llllll}
\hline Sample data & \multicolumn{5}{l}{ Results } \\
\cline { 2 - 6 } & SNA content \% & & & \\
\cline { 2 - 6 } Sample code & G0-G1\% & S\% & G2-M\% & Pre G1\% & Comment \\
\hline Artichoke extract/SCC25 & $39.52 \pm 1.47$ & $28.49 \pm 1.82$ & $31.99 \pm 1.29$ & $9.42 \pm 0.22$ & Cell growth arrest at G2/M \\
Control/SCC25 & $46.72 \pm 2.15$ & $32.07 \pm 1.29$ & $21.21 \pm 1.61$ & $2.06 \pm 0.09$ & - \\
\hline
\end{tabular}




\section{DNA Content}

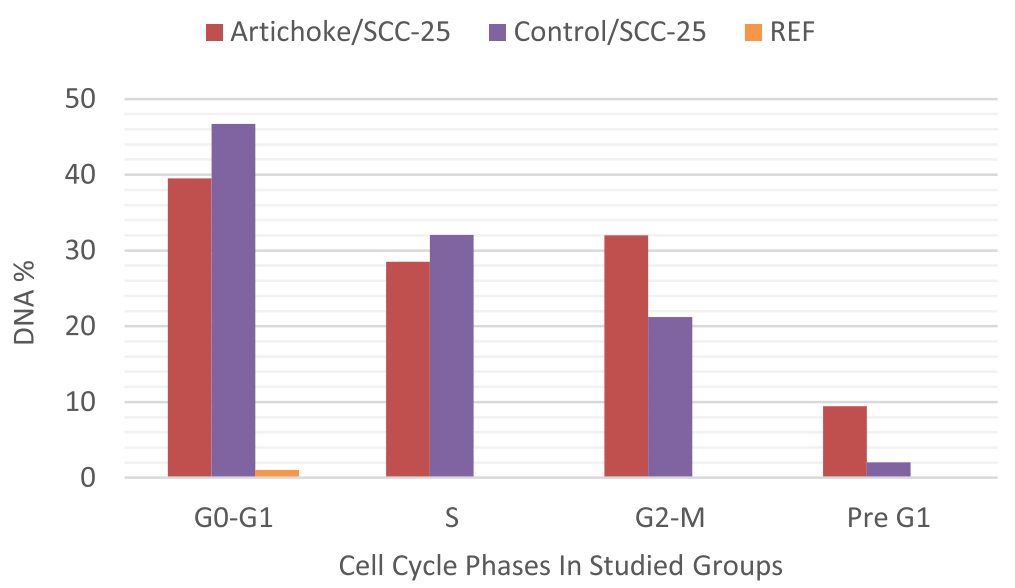

Fig. 6 Percentage of DNA content in control and artichoke SCC cell lines during flow cytometry cell cycle analysis

proportional to the decreased expression of $\mathrm{Bcl}-2$ gene. These findings were in the same line of our previous study and were consistent with other studies [28, 29].

In our study, apoptotic cells from artichoke extract treatment showed that the cell cycle was arrested at G2/ $\mathrm{M}$ phase. Moreover, defects in the G2/M arrest checkpoint allow a damaged cell to enter mitosis and undergo apoptosis and this enhances the increase of the cytotoxic effects of the therapeutic drugs [20, 29]. For this reason, our results suggest that artichoke extract induced cellcycle G2/M phase arrest and apoptosis in SCC-25.

\section{Conclusion}

Artichoke medicinal plants have the potential to become a safe anti-carcinogenic agent. It has a cytotoxic and inhibitory effect on cancer cell proliferation through induction of apoptosis. Further studies are needed to prove the anticancer activities of artichoke especially in head and neck cancers.

\section{Abbreviations}

CASP-9: Caspase-9; ChA: Chlorogenic acid; Ct: Threshold cycle; FITC: Fluorescein isothiocyanate; HPRI: Human placental ribonuclease inhibitor; MMLV: Moloney murine leukemia virus; MTT assay: Micro-culture tetrazolium assay; OSCC: Oral squamous cell carcinoma; PI: Propidium iodide; PS: Phosphatidylserine; SCC: Squamous cell carcinoma

\section{Acknowledgements}

Not applicable.

\section{Authors' contributions}

NFH performed the morphological investigation of apoptosis by inverted light microscope and was responsible for reviewing literature and writing the background, material and methods, and submission process to JECI. AFF analyzed the cell population identified in the current study by flow cytometry analysis and was a major contributor in writing the discussion and results and carried out the preparation of manuscript. All authors have read and approved the final manuscript.

\section{Funding}

None. This research did not receive any specific grant from funding agencies in the public, commercial, or not-for-profit sectors.

Availability of data and materials

Not applicable.

\section{Ethics approval and consent to participate}

Not applicable: This article does not contain any studies with human or animal subjects, only Human tongue SCC cell lines (SCC-25) obtained from American Type Culture Collection, and cells were cultured using DMEM (Invitrogen/Life Technologies) by the Holding Company for Biological Products \& Vaccines, Egypt (VACSERA) and were used in the present study. No approvals were required for the study, which complied with all relevant regulations.

Consent for publication

Not applicable.

\section{Competing interests}

The authors declare that they have no competing interests associated with this publication.

Received: 9 October 2019 Accepted: 24 February 2020 Published online: 05 April 2020

\section{References}

1. Jiang X, Wu J, Wang J, Huang R. Tobacco and oral squamous cell carcinoma: a review of carcinogenic pathways. Tob Induc Dis 2019;17(April): $1-9$.

2. Oral Cancer in Egypt [Internet]. [cited 2020 Jan 28]. Available from: https:// www.worldlifeexpectancy.com/egypt-oral-cancer.

3. Mokhtari RB, Homayouni TS, Baluch N, Morgatskaya E, Kumar S, Das B, et al. Combination therapy in combating cancer. Oncotarget. 2017:8(23):38022-43.

4. Mileo AM, Miccadei S. Polyphenols as modulator of oxidative stress in cancer disease: new therapeutic strategies. Oxidative Med Cell Longev. 2016;2016:6475624.

5. Mileo AM, Di Venere D, Mardente S, Miccadei S. Artichoke polyphenols sensitize human breast cancer cells to chemotherapeutic drugs via a ROSmediated downregulation of flap endonuclease 1. 2020;2020

6. Alonso-Castro AJ, Villarreal ML, Salazar-Olivo LA, Gomez-Sanchez M, Dominguez F, Garcia-Carranca A. Mexican medicinal plants used for cancer treatment: pharmacological, phytochemical and ethnobotanical studies. J Ethnopharmacol. 2011;133(3):945-72.

7. Baliga MS, Dsouza JJ. Amla (Emblica officinalis Gaertn), a wonder berry in the treatment and prevention of cancer. Eur J Cancer Prev. 2011;20(3):225-39. 
8. Dominguez M, Avila JG, Nieto A, Cespedes CL. Anti-inflammatory activity of Penstemon gentianoides and Penstemon campanulatus. Pharm Biol. 2011; 49(2):118-24.

9. Namasivayam N. Chemoprevention in experimental animals. Ann N Y Acad Sci. 2011;1215:60-71.

10. Weng C-J, Yen G-C. Chemopreventive effects of dietary phytochemicals against cancer invasion and metastasis: phenolic acids, monophenol, polyphenol, and their derivatives. Cancer Treat Rev. 2012;38(1):76-87.

11. Szliszka E, Krol W. The role of dietary polyphenols in tumor necrosis factorrelated apoptosis inducing ligand (TRAIL)-induced apoptosis for cancer chemoprevention. Eur J Cancer Prev. 2011;20(1):63-9.

12. Azzini E, Bugianesi R, Romano F, Di Venere D, Miccadei S, Durazzo A, et al. Absorption and metabolism of bioactive molecules after oral consumption of cooked edible heads of Cynara scolymus L. (cultivar Violetto di Provenza) in human subjects: a pilot study. Br J Nutr. 2007:97(5):963-9.

13. Zhu X, Zhang H, Lo R. Phenolic compounds from the leaf extract of artichoke (Cynara scolymus L.) and their antimicrobial activities. J Agric Food Chem. 2004;52(24):7272-8.

14. Miadokova E, Nadova S, VIckova V, Duhova V, Kopaskova M, Cipak L, et al. Antigenotoxic effect of extract from Cynara cardunculus L. Phytother Res. 2008;22(1):77-81.

15. Miccadei S, Di Venere D, Cardinali A, Romano F, Durazzo A, Foddai MS, et al. Antioxidative and apoptotic properties of polyphenolic extracts from edible part of artichoke (Cynara scolymus L.) on cultured rat hepatocytes and on human hepatoma cells. Nutr Cancer. 2008;60(2):276-83.

16. Mileo AM, Di Venere D, Linsalata V, Fraioli R, Miccadei S. Artichoke polyphenols induce apoptosis and decrease the invasive potential of the human breast cancer cell line MDA-MB231. J Cell Physiol. 2012;227(9):3301-9.

17. Vígh S, Zsvér-Vadas Z, Pribac C, Moş L, Cziáky Z, Czapár M, et al. Artichoke (Cynara scolymus L.) extracts are showing concentration-dependent hormetic and cytotoxic effects on breast cancer cell lines. Stud Univ Vasile Goldis Arad, Ser Stiint Vietii. 2016;26(4):423-33.

18. Wong ML, Medrano JF. Real-time PCR for mRNA quantitation. Biotechniques. 2005;39(1):75-85.

19. Sosa V, Moline T, Somoza R, Paciucci R, Kondoh H, LLeonart ME. Oxidative stress and cancer: an overview. Ageing Res Rev. 2013;12(1):376-90.

20. Fitzmaurice C, Allen C, Barber RM, Barregard L, Bhutta ZA, Brenner H, et al. Global, regional, and national cancer incidence, mortality, years of life lost, years lived with disability, and disability-adjusted life-years for 32 cancer groups, 1990 to 2015: a systematic analysis for the Global Burden of Disease Study Global Burden. JAMA Oncol [Internet]. 2017;3(4):524-48. Available from: http://oncology.jamanetwork.com/article.aspx?doi=10.1001/ jamaoncol.2016.5688.

21. Guina T, Biasi F, Calfapietra S, Nano M, Poli G. Inflammatory and redox reactions in colorectal carcinogenesis. Ann N Y Acad Sci. 2015;1340:95-103.

22. Mileo AM, Di Venere D, Abbruzzese C, Miccadei S. Long term exposure to polyphenols of artichoke (cynara scolymus L.) exerts induction of senescence driven growth arrest in the MDA-MB231 human breast cancer cell line. Oxid Med Cell Longev. 2015;2015.

23. Blanco E, Sabetta W, Danzi D, Negro D, Passeri V, De Lisi A, et al. Isolation and characterization of the flavonol regulator CCMYB12 from the globe artichoke [Cynara cardunculus var. scolymus (L.) Fiori]. Front Plant Sci. 2018:9:941.

24. Darvesh AS, Bishayee A. Chemopreventive and therapeutic potential of tea polyphenols in hepatocellular cancer. Nutr Cancer. 2013;65(3):329-44.

25. Metwally NS, Kholeif TE, Ghanem KZ, Farrag ARH, Ammar NM, Abdel-Hamid AHZ. The protective effects of fish oil and artichoke on hepatocellular carcinoma in rats. Eur Rev Med Pharmacol Sci. 2011;15(12):1429-44.

26. Portt L, Norman G, Clapp C, Greenwood M, Greenwood MT. Anti-apoptosis and cell survival: a review. Biochim Biophys Acta. 2011;1813(1):238-59.

27. Kwan YP, Saito T, Ibrahim D, Al-Hassan FMS, Ein Oon C, Chen Y, et al. Evaluation of the cytotoxicity, cell-cycle arrest, and apoptotic induction by Euphorbia hirta in MCF-7 breast cancer cells. Pharm Biol. 2016;54(7):1223-36.

28. Hassabou N, Kamel S. Effect of pomegranate (Punica Granatum) extract on nasopharyngeal carcinoma cell lines. Int J Adv Res. 2017;5(12):748-56.

29. Thangam R, Sathuvan M, Poongodi A, Suresh V, Pazhanichamy K, Sivasubramanian $S$, et al. Activation of intrinsic apoptotic signaling pathway in cancer cells by Cymbopogon citratus polysaccharide fractions. Carbohydr Polym. 2014;107:138-50.

\section{Publisher's Note}

Springer Nature remains neutral with regard to jurisdictional claims in published maps and institutional affiliations.

\section{Submit your manuscript to a SpringerOpen ${ }^{\circ}$ journal and benefit from:}

- Convenient online submission

- Rigorous peer review

- Open access: articles freely available online

- High visibility within the field

- Retaining the copyright to your article

Submit your next manuscript at $\boldsymbol{\nabla}$ springeropen.com 